\title{
Novel cardiac peptide hormone in several teleosts
}

\author{
V Tervonen, $\mathbf{H}$ Ruskoaho ${ }^{1}$ and $\mathbf{O}$ Vuolteenaho \\ Department of Physiology, Biocenter Oulu, University of Oulu, POB 5000, FIN-90014 University of Oulu, Finland \\ ${ }^{1}$ Department of Pharmacology and Toxicology, Biocenter Oulu, University of Oulu, POB 5000, FIN-90014 University of Oulu, Finland \\ (Requests for offprints should be addressed to O Vuolteenaho; Email: olli.vuolteenaho@oulu.fi)
}

\begin{abstract}
To find out the significance of the newest member of the natriuretic peptide family, salmon cardiac peptide (sCP), we have determined the distribution of the peptide and its mRNA as well as the tissue and plasma molecular forms in several teleosts. Using probes based on the salmon sCP cDNA in Northern blot analysis we found mRNA homologous to that of sCP to be present in the heart of 15 fish species representing nine different genera. We developed a specific RIA for the salmon 29 amino acid peptide to be able to study the distribution of the peptide in the heart and plasma of different fish species. Despite the probable interspecies differences in the peptide sequence, large quantities of immunoreactive sCP were found in the atrium, ventricle and plasma of most of the fish species studied, suggesting that a cardiac hormone homologous to sCP has an endocrine function in a large variety of teleost species. The molecular form of the hormone secreted and stored in the tissue was determined
\end{abstract}

by gel filtration high pressure liquid chromatography. In salmon, as in most of the other fish species studied, the predominant immunoreactive $\mathrm{sCP}$ in plasma corresponded to the low molecular weight form, with a size similar to that of the biologically active 29 amino acid sCP (sCP-29), whereas the form stored in the heart corresponded to the high molecular weight pro-sCP-sized material. The form secreted by isolated perfused salmon ventricle, in the basal state as well as when mechanically loaded, was the sCP-29-sized peptide, thus ruling out the possibility that the conversion from high to low molecular weight material is caused by plasma proteases. In conclusion, sCP-like peptides are produced and secreted from the heart of a large number of different fish species. Their post-translational processing appears to be remarkably similar to that of mammalian atrial natriuretic peptide.

Journal of Endocrinology (2000) 166, 407-418

\section{Introduction}

Despite extensive research the exact role of the natriuretic peptides in the regulation of fluid and salt balance and cardiovascular function is incompletely understood. Knowing the evolution of the natriuretic peptide system could help us to define its homeostatic significance. The evolutionary position of fish is ideal for studying organismic and molecular evolution. Fish, the largest group of vertebrates, offer a large number of models for examining the different strategies and mechanisms used in adapting to diverse environments (Powers 1989). Salmon (Salmo salar) faces both hypo-osmotic and hyperosmotic environments in its natural life cycle, and therefore its water and electrolyte retaining and expelling mechanisms are well developed. In sea water it tends to lose volume and gain salt, the reverse being true in fresh water. We have used salmon as a model system for studies aimed at clarifying the molecular mechanisms of extracellular fluid volume regulation. As a part of these studies, we recently cloned and characterised from salmon heart a new peptide hormone belonging to the natriuretic peptide family (Tervonen et al. 1998). The new salmon cardiac peptide (sCP) has a unique combination of structural and functional properties, suggesting that it does not belong to any of the formerly known natriuretric peptide subgroups, but rather appears to be a mixture of the A-, B- and C-type natriuretic peptides.

To study the regulation and mechanisms of release of $\mathrm{sCP}$, a method for measurement of its concentrations in blood and tissue samples is required. We describe here the development and application of a specific radioimmunoassay (RIA) for sCP. Using the RIA we have studied the distribution and molecular forms of sCP-like immunoreactivity stored in the heart of salmon and several other teleost species. We have also determined the level and molecular form of immunoreactive $\mathrm{sCP}$ (ir-sCP) present in teleost plasma, as well as the form secreted by isolated perfused salmon heart, both in basal conditions and when mechanically loaded.

\section{Materials and Methods}

\section{Experimental animals}

The experimental design was approved by the Animal Experimentation Review Board of the University of Oulu 
(permit 8/97 to O V). Salmon (Salmo salar), landlocked salmon (Salmo salar m. sebago), brown trout (Salmo trutta $m$. lacustris), sea trout (Salmo trutta m. trutta), rainbow trout (Oncorhynchus mykiss), lake trout (Salvelinus namaycush), arctic char (Salvelinus alpinus), grayling (Thymallus thymallus), vendace (Coregonus albula), migrating whitefish (Coregonus lavaretus) and Coregonus pallasi were obtained from the Game and Fisheries Research Institute, Taivalkoski, Finland $\left(28^{\circ} 25^{\prime} \mathrm{N}, 65^{\circ} 57^{\prime} \mathrm{E}\right)$. The mature adults of both sexes were kept in fresh water and under natural photoperiod and temperature. Tissue samples were collected in October when the water temperature was $0.5{ }^{\circ} \mathrm{C}$ and the photoperiod $11 \mathrm{~h}$ light: $13 \mathrm{~h}$ darkness. The perfusion experiments with salmon ventricle were performed during April when the natural water temperature was $1{ }^{\circ} \mathrm{C}$. The salmon were allowed to adapt in a 1500 litre tank with dechlorinated, well aerated and circulating tap water for approximately 4 days. The water temperature in the tank was kept at $6{ }^{\circ} \mathrm{C}$ and the photoperiod at $8 \mathrm{~h}$ light:16 h darkness. For tissue sampling, the fish were killed with a blow on the head. A blood sample from the caudal vein was drawn immediately in a chilled $\mathrm{K}_{2}$ EDTA tube using a heparinised needle. The plasma, obtained by centrifugation at $4{ }^{\circ} \mathrm{C}$, was stored at $-70{ }^{\circ} \mathrm{C}$. Tissue samples were collected directly after the blood sample, frozen in liquid $\mathrm{N}_{2}$ and stored at $-70{ }^{\circ} \mathrm{C}$.

The arctic fish studied were eel pout (Lycodes vahlii), Atlantic wolf fish (Anarhichas lupus), common sculpin (Myoxocephalus scorpius), dusky snailfish (Liparis gibbus) and Greenland cod (Gadus ogac). They were caught in Disko Bay and Disko Fjord in Greenland during the month of August. The hearts of the freshly killed animals were immediately stored at $-70{ }^{\circ} \mathrm{C}$.

Other heart tissue samples were from lamprey (Lampetra fluviatilis), frog (Xenopus sp.), fin whale (Balaenoptera physalus), rat, cow and man.

\section{Radioimmunoassay}

Preparation of antiserum to $\mathbf{s C P}$ To set up an $\mathrm{sCP}$ RIA, we synthesised a 29 amino acid cyclic sCP with the sequence Ser-Lys-Ala-Met-Ser-Gly-Cys-Phe-GlyAla-Arg-Met-Asp-Arg-lle-Gly-Thr-Ser-Ser-Gly-Leu-GlyCys-Ser-Pro-Lys-Arg-Arg-Ser (sCP-29), as well as an analogue with an extra tyrosine at the $\mathrm{NH}_{2}$-terminal end. Final purification of the peptides was done by reverse-phase high pressure liquid chromatography (RP-HPLC). The structures were confirmed with amino acid analysis and mass spectrometry. For immunisation, the synthetic sCP was conjugated to bovine thyroglobulin with water-soluble carbodi-imide as described previously (Vuolteenaho et al. 1981). The conjugate, purified by dialysis against two changes of 2 litres $0.9 \% \mathrm{NaCl}$, was emulsified in Freund's complete adjuvant (Difco Laboratories, Detroit, MI, USA), and injected subcutaneously at multiple sites on the back of two White New Zealand rabbits and a male goat. Boosters, emulsified in Freund's incomplete adjuvant, were given at 3- to 5-week intervals.

Radioiodination Synthetic $\mathrm{Tyr}_{0}-\mathrm{sCP}$ was radiolabelled with ${ }^{125}$ I using the chloramine-T technique (Hunter \& Greenwood 1962). In brief, $5 \mu \mathrm{g}$ chloramine-T was added in $10 \mu \mathrm{l} \quad 0.25 \mathrm{~mol} / 1 \quad \mathrm{Na}_{2} \mathrm{HPO}_{4} / \mathrm{NaH}_{2} \mathrm{PO}_{4}(\mathrm{pH} 7 \cdot 4)$ to $30 \mu 110 \mathrm{mmol} / 1 \mathrm{HCl}$ containing $2 \mu \mathrm{g} \mathrm{Tyr}_{0}-\mathrm{sCP}-30$ and $0.5 \mathrm{mCi} \mathrm{Na}{ }^{125} \mathrm{I}$ (Amersham-Pharmacia Biotech, Little Chalfont, Bucks, UK). After $5 \mathrm{~s}$ the reaction was stopped with $10 \mu \mathrm{g}$ sodium metabisulfite in $10 \mu \mathrm{l}$ of the phosphate buffer. The labelled peptide was desalted by gel filtration in a $2 \mathrm{ml}$ Sephadex G-25 M column (Pharmacia, Uppsala, Sweden). The void volume fraction was purified further by RP-HPLC using a $4 \cdot 6 \times 250 \mathrm{~mm}$ Vydac $\mathrm{C}_{18}$ column (Separation Group, Hesperia, CA, USA) and a 30-min linear gradient from 10 to $40 \%$ acetonitrile in aqueous trifluoroacetic acid (TFA). The radioactivity of the RPHPLC fractions was counted in an LKB MultiGamma gamma counter and the peak fractions were tested for binding and sensitivity in the sCP RIA. The iodinated peptide was divided into aliquots and stored at $-20{ }^{\circ} \mathrm{C}$.

RIA procedure All dilutions were made with the RIA buffer consisting of $0.1 \mathrm{M}$ sodium phosphate, $0.05 \mathrm{M}$ $\mathrm{NaCl}, 0 \cdot 1 \%$ gelatin, $0 \cdot 05 \%$ Triton-X and $0 \cdot 1 \% \mathrm{NaN}_{3}$, $\mathrm{pH} \mathrm{7 \cdot 4}$. Standards (synthetic sCP-29 in concentrations ranging from 8.19 to $2000 \mathrm{pg} /$ tube) and samples were pipetted in duplicates of $100 \mu \mathrm{l}$ in polystyrene tubes. The goat anti-sCP antiserum 'Pelle' (final dilution of 1/8000) was added in $100 \mu$ followed by an overnight incubation at $4{ }^{\circ} \mathrm{C} .{ }^{125} \mathrm{I}^{-\mathrm{Tyr}_{0}}-\mathrm{sCP}(6000-10000$ c.p.m. $)$ was then added in $100 \mu \mathrm{l}$ and the incubation was continued for another $16-20 \mathrm{~h}$ at $4{ }^{\circ} \mathrm{C}$. The bound and free fractions were separated by double antibody precipitation. The tubes were centrifuged $(2000 \mathrm{~g}, 15 \mathrm{~min})$, the supernatants aspirated and the precipitates counted in an LKB CliniGamma gamma counter. The specificity of the antiserum was tested using the following synthetic peptides purchased from Peninsula Laboratories Europe (St Helens, Merseyside, UK): rat A-type natriuretic peptide (ANP), porcine B-type natriuretic peptide (BNP), human C-type natriuretic peptide (CNP), eel ANP and rainbow trout ventricular natriuretic peptide (VNP).

\section{Extraction of $s C P$ from plasma and tissues}

To concentrate and purify the plasma samples $(0 \cdot 5-1 \mathrm{ml})$, they were extracted with SepPak $\mathrm{C}_{18}$ cartridges (Waters, Milford, MA, USA) as follows. The plasma samples were first acidified with $1 \mathrm{~mol} / 1 \mathrm{HCl}$ and $0.2 \mathrm{~mol} / 1$ glycine $(200 \mu \mathrm{l} / \mathrm{ml}$ plasma) to inhibit proteolytic enzymes and to enhance peptide binding to the resin. The samples were loaded into the SepPak $\mathrm{C}_{18}$ cartridges that had been preactivated with isopropanol and aqueous $0 \cdot 1 \%$ TFA. 
Following a wash with $10 \mathrm{ml} \mathrm{0 \cdot 1 \%}$ TFA, the peptide fraction was eluted with $2 \mathrm{ml} 40 \%$ acetonitrile in aqueous $0.1 \%$ TFA, dried in a Savant Speed Vac concentrator and dissolved in RIA buffer. Aliquots from the guanidine isothiocyanate/2-mercaptoethanol homogenates prepared in the course of RNA isolation (see below) were used for the RIA of tissue ir-sCP and for gel filtration HPLC. Because of interference with larger volumes by the chaotropic extraction solution, no more than $1 \mu \mathrm{l}$ of the tissue homogenate, diluted with the assay buffer, was used directly in the RIA.

\section{Isolation of $m R N A$ and Northern blot analysis}

Northern blot analysis was used to detect sCP mRNA in the tissue samples and to detemine its size. The tissue samples were pulverised in liquid $\mathrm{N}_{2}$ and homogenised in 9 volumes of $4 \mathrm{M}$ guanidium thiocyanate, $8 \%$ 2-mercaptoethanol, $50 \mathrm{mM}$ Tris- $\mathrm{HCl}, 10 \mathrm{mM}$ EDTA, $\mathrm{pH} 7 \cdot 5$, conditions that inhibit enzyme activity and RNA degration. Aliquots of each homogenate were stored at $-70{ }^{\circ} \mathrm{C}$ for use in RIA and HPLC. Total RNA was isolated from the remaining homogenates with the acidicphenol method (Chomczynski \& Sacchi 1987). Five microgram samples of teleost RNA and $20 \mu \mathrm{g}$ samples of RNA of other animals were separated by electrophoresis on $1 \%$ agarose gels, blotted on nylon membranes and fixed by baking at $80{ }^{\circ} \mathrm{C}$ for $2 \mathrm{~h}$. One microgram of salmon atrium RNA was electrophoresed and blotted as size reference. The membranes were hybridised in $6 \times \mathrm{SSC} /$ $0 \cdot 2 \%$ SDS overnight at $65^{\circ} \mathrm{C}$ using sCP cDNA probes labelled to a specific activity of $>10^{8}$ d.p.m. $/ \mu \mathrm{g}$ by random primed labelling and purified by Sephadex G-50 gel filtration. The insert of a full length (1234 bp) sCP cDNA clone (Tervonen et al. 1998) was used as the probe. However, for RNA obtained from the phylogenetically more distant arctic fish and animals other than teleosts, a $229 \mathrm{bp}$ probe was used, which corresponds to the sequence encoding the conserved cysteine ring structure of the salmon peptide, with short stretches of the neighbouring sequence. The probe was prepared by RT-PCR using the $1234 \mathrm{bp}$ sCP cDNA as the template, and CCTGAA CACAGTAAGGCT and GGACTGCAGCCTAAACC GCTCG as the sense and antisense primers, corresponding to nucleotides $237-254$ and $466-445$ of the sCP cDNA respectively (Tervonen et al. 1998; European Molecular Biology Laboratory (EMBL) nucleotide sequence data base, accession number AJ001806). The membranes were washed for $30 \mathrm{~min}$ at room temperature and $60 \mathrm{~min}$ at $65{ }^{\circ} \mathrm{C}$ with $0 \cdot 2 \times$ SSC containing $0.2 \%$ SDS or $60 \mathrm{~min}$ at $65{ }^{\circ} \mathrm{C}$ with $1 \times$ SSC containing $0 \cdot 2 \%$ SDS (samples of arctic fish and other animals), and used to expose X-Omat film (Kodak, Rochester, NY, USA) with an intensifying screen at $-70{ }^{\circ} \mathrm{C}$ for $1.5 \mathrm{~h}$ at room temperature or 4 days at $-70{ }^{\circ} \mathrm{C}$ (arctic fishes and other animals). The results were normalised to the RNA load by hybridising the same membranes with a $482 \mathrm{bp}$ ribosomal (r) $18 \mathrm{~S}$ cDNA probe corresponding to the sequence $922-1403$ of the rat gene for r18S RNA (Torczynski et al. 1983). The extremely conserved r18S sequence chosen shows $99 \cdot 8 \%$ homology between rat and human and 98\% homology between rat and teleost or elasmobranch fishes. The r18S probe was prepared by RT-PCR and the DNA sequence was confirmed using the dideoxy method. Following a strip wash of the membranes with $0.05 \times \mathrm{SSC}, 0.5 \mathrm{~mol} / 1$ EDTA and $10 \%$ SDS at $95{ }^{\circ} \mathrm{C}$ for $30 \mathrm{~min}$, the hybridisations were performed as described above for sCP. The Northern blot films were digitised using a Macintosh personal computer, a U-Max flat bed scanner, and Adobe Photoshop (Adobe Systems Inc., San Jose, CA, USA). The hybridisation signals were quantified with ScanAnalysis (Biosoft, Cambridge, Cambs, UK).

\section{Isolated perfused salmon ventricle preparation}

We used an isolated perfused salmon ventricle preparation to determine whether the exclusion of the components of plasma or the application of mechanical load have an influence on the molecular form of the secreted ir-sCP. Ventricles $(1 \cdot 0 \pm 0 \cdot 1 \mathrm{~g})$ of adult freshwater salmon $(906 \pm 143 \mathrm{~g})$ were mounted in an organ bath with a constant temperature of $8{ }^{\circ} \mathrm{C}$, and perfused with a modified version of Cortland saline containing $124 \mathrm{mmol} \mathrm{NaCl}$, $5 \mathrm{mmol} \mathrm{CaCl}_{2} 2 \mathrm{H}_{2} \mathrm{O}, 3 \mathrm{mmol} \mathrm{KCl}, 0.09 \mathrm{mmol} \mathrm{NaH}_{2}-$ $\mathrm{PO}_{4} .2 \mathrm{H}_{2} \mathrm{O}, \quad 1.8 \mathrm{mmol} \quad \mathrm{NaHPO}_{4} .2 \mathrm{H}_{2} \mathrm{O}, \quad 1.1 \mathrm{mmol}$ $\mathrm{MgSO}_{4} \cdot 6 \mathrm{H}_{2} \mathrm{O}, 5.6 \mathrm{mmol}$ dextrose and $12 \mathrm{mmol}$ $\mathrm{NaHCO}_{3}(280 \mathrm{mOsm}, \mathrm{pH} 7 \cdot 5)$. The perfusate was gassed with $95 \% \mathrm{O}_{2}, 5 \% \mathrm{CO}_{2}$. The perfusion rate was $1.5 \mathrm{ml} / \mathrm{min}$. The ventricle was paced supramaximally 12 times/min with a silver electrode placed near the atrioventricular node and a platinum electrode at the bottom of the organ bath. The contractions were monitored with a polygraph. The preparation was allowed to equilibrate for $60 \mathrm{~min}$ before starting the experiment. After perfusion for $60 \mathrm{~min}$, the ventricle was subjected for $60 \mathrm{~min}$ to mechanical load of $10 \mathrm{mmHg}(1.33 \mathrm{kPa})$, produced by adjusting the outflow height of the perfusate. Fractions of $7.5 \mathrm{ml}$ were collected at 5-min intervals to measure the concentration of ir-sCP in the perfusate. Fractions were stored at $-20{ }^{\circ} \mathrm{C}$ until analysed. The ir-sCP level was measured directly from $100 \mu$ laliquots of the perfusate fractions and expressed as pmol/1 ir-sCP secreted/g tissue wet weight. Control perfusions were performed identically, except for the mechanical load, to verify the specificity of the effect of load on the ir-sCP release.

\section{Gel filtration HPLC}

Gel filtration HPLC and sCP RIA were used to characterise the molecular form of ir-sCP in the cardiac tissue and plasma of fish and in the perfusates from 
salmon ventricle. Aliquots of atrial and ventricle tissue homogenates from RNA isolation were diluted to $400 \mu \mathrm{l}$ with $40 \%$ acetonitrile in aqueous $0 \cdot 1 \%$ TFA. Samples $(3 \mathrm{ml})$ of the acidified ventricular perfusates were extracted with SepPak $\mathrm{C}_{18}$ cartridges as described for the plasma samples. The dried extracts were reconstituted in $400 \mu \mathrm{l} 40 \%$ acetonitrile in aqueous $0 \cdot 1 \%$ TFA. To find out whether the extraction procedure alters the chromatography profile, $300 \mu$ samples of the perfusate were diluted with $200 \mu \mathrm{l} 0 \cdot 25 \%$ TFA in acetonitrile and subjected directly to the gel filtration HPLC. All samples were passed through Millex HV filters (Millipore, Bedford, MA, USA) before being loaded via a Rheodyne Loop injector (Rheodyne, Cotati, CA, USA) into the $7.8 \times 300 \mathrm{~mm}$ ProteinPak-125 column (Waters). The column was eluted with $40 \%$ acetonitrile in aqueous $0 \cdot 1 \%$ TFA at $1 \mathrm{ml} / \mathrm{min}$. Fractions of $0.5 \mathrm{ml}$ were collected, dried in a Savant SpeedVac and subjected in duplicate to sCP RIA. The column was calibrated with bovine serum albumin (BSA; $68 \mathrm{kDa}$, void volume), human proANP (14 kDa), synthetic sCP-29 (3 kDa) and ${ }^{125} \mathrm{I}$ (total volume).

\section{Statistical analyses}

The data were analysed with unpaired Student's $t$-test using GraphPad InStat Mac (GraphPad Software, Inc., San Diego, CA, USA). Differences at the 95\% level were considered statistically significant. All results are expressed as means \pm S.E.M.

\section{Results}

\section{Characteristics of $s C P$ RIA}

Since the sequence of sCP does not contain tyrosine or histidine, residues required for radioiodination, a synthetic analogue with an extra tyrosine at the $\mathrm{NH}_{2}$-terminal end was synthesised. Despite the fact that there are two methionines in sCP, a residue notoriously prone to oxidative modification, ${ }^{125} \mathrm{I}-\mathrm{sCP}$ prepared by the chloramine-T procedure and purified by RP-HPLC was stable in storage for about 4 weeks and showed consistent binding to the antiserum which could be efficiently competed by native sCP.

The cross-reaction studies demonstrated that our antiserum 'Pelle' is highly specific for sCP. Since sCP shows higher homology to mammalian ANP and BNP than to teleost natriuretic peptides (Tervonen et al. 1998), the specificity was initially tested with rat ANP and porcine $\mathrm{BNP}$ and the cross-reactions were found to be $<0 \cdot 1 \%$ on a molar basis. The teleost peptides eel ANP and rainbow trout VNP, fish natriuretic peptides potentially more troublesome with regard to the specificity of the antiserum, were not recognised at all by the antiserum (cross-reaction $<0 \cdot 01 \%)$. Eel CNP appears not to be commercially available, but the close homologue human
CNP cross-reacted $<0 \cdot 01 \%$, indicating that the CNPs are not recognised by our sCP antiserum. The lowest detectable dose in the RIA was $10 \mathrm{pg} /$ tube, which produced $\geq 5 \%$ displacement of the tracer. The intra- and interassay coefficients of variation were $<10 \%$ and $<15 \% \quad(n=30)$ respectively. To exclude the possibility that proteolytic enzymes in tissue extracts cause artefactual results by degrading immunoreactive material or tracer during the extraction procedure or assay incubation, boiled and nonboiled extracts of salmon heart were tested. They both contained the same amount of immunoreactivity and produced displacement curves parallel to that produced by synthetic sCP. To confirm that sCP RIA can be used for measurement of ir-sCP-like material in plasma of salmon and also in other fish species, plasma extracts of representatives of three different genera were tested. As shown in Fig. 1, plasma extracts of salmon, rainbow trout and migrating whitefish produced displacement curves parallel to that produced by synthetic sCP.

\section{Distribution of ir-sCP and $s C P m R N A$ in the heart of different species}

To quantify the amount of immunoreactive material in the atrium and ventricle of different fish species, aliquots of the tissue homogenates were subjected to sCP RIA. High levels of immunoreactivity were detected in freshwater salmon atrium $(54.6 \pm 3.9 \mathrm{nmol} / \mathrm{g})$ and ventricle $(7 \cdot 4 \pm 0.9 \mathrm{nmol} / \mathrm{g})$. The levels were undetectable $(<0.003 \mathrm{nmol} / \mathrm{g})$ in bulbus arteriosus, brain, intestine, kidney, skeletal muscle and gill.

Large quantities of ir-sCP were also detected in the heart of several other teleost species (Table 1). The highest concentration of ir-sCP was measured in the atrium of vendace $(121.9 \pm 12.0 \mathrm{nmol} / \mathrm{g})$. On the other hand, in this species the ir-sCP level in the ventricle was relatively low $(4 \cdot 1 \pm 0.4 \mathrm{nmol} / \mathrm{g})$, resulting in the highest atrium to ventricle ratio $(32.7 \pm 8 \cdot 1)$ of all the species studied. The atrium to ventricle ratio in the other two members of the family Coregonus studied was $8.4 \pm 3.0$ in migrating whitefish and $8.0 \pm 1.6$ in C. pallasi. Rainbow trout had fairly high concentrations of ir-sCP in both the atrium and ventricle, with the lowest atrium to ventricle ratio of $2 \cdot 3 \pm 0 \cdot 6$. No ir-sCP was detected in the hearts of lamprey, arctic fish, frog, fin whale, rat, cow or man. The measured concentrations of ir-sCP in species other than salmon must be interpreted with caution since the peptide sequences and hence the cross-reactivities are not known. The levels are, however, more likely to err on the low rather than the high side.

sCP mRNA was detected by Northern blot analysis, utilising cDNA probes based on the salmon sequence, in the hearts of all the teleost species studied, with the sole exception of dusky snailfish. Considering the use of relatively stringent hybridisation conditions, the result indicated that a gene closely homologous to that of $\mathrm{sCP}$ is 


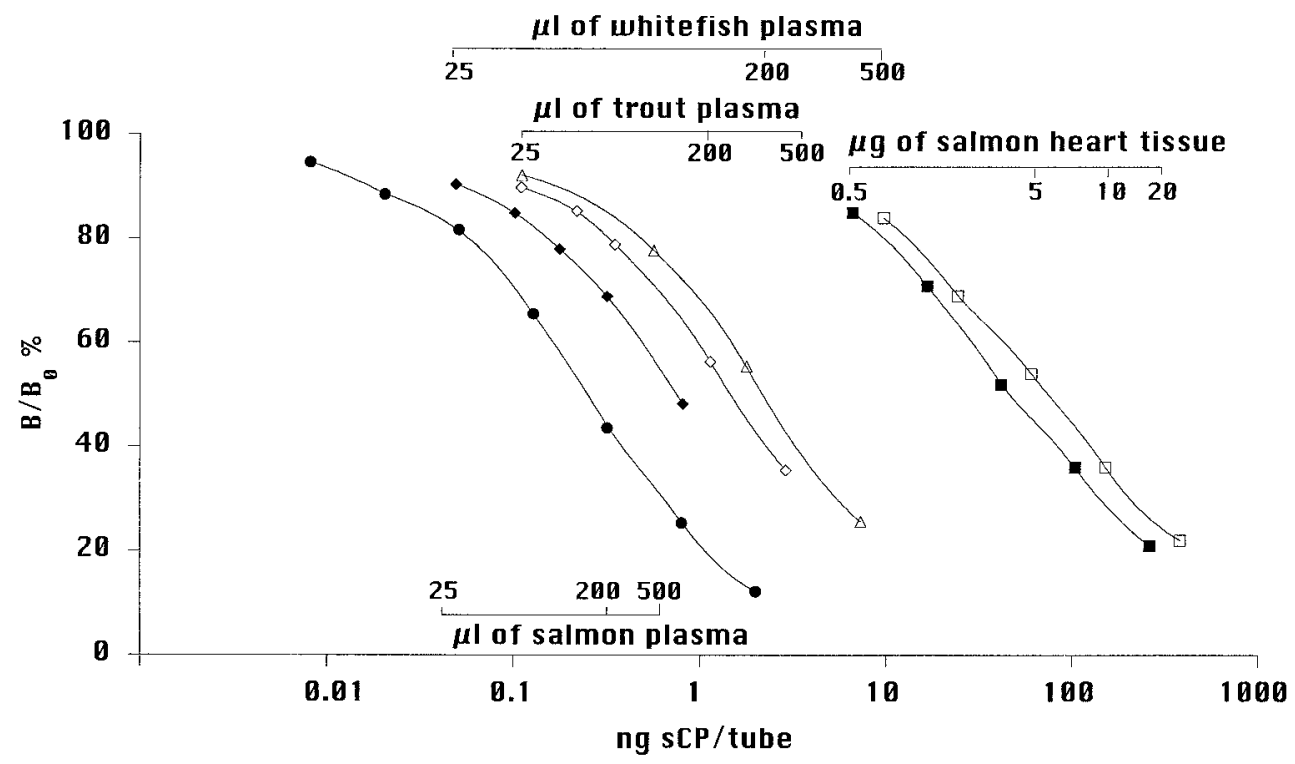

Figure 1 Dose-response curves showing the displacement of ${ }^{125} \mathrm{I}-\mathrm{sCP}$ from binding to the specific antiserum by synthetic sCP standard ( $)$ and extracts of salmon heart (boiled: $\mathbf{\square}$; non-boiled: $\square$ ) and plasma $(\diamond)$, and rainbow trout $(\diamond)$ and migrating whitefish plasma $(\triangle)$.

widely expressed in teleost fish. Moreover, only one hybridising band was observed. There was some variation in the mRNA size in that, while mRNA with a similar size as that in salmon $(\approx 1.3 \mathrm{~kb})$ was detected in the majority of the species, the coregonids demonstrated a band of $\approx 1.5 \mathrm{~kb}$ (Fig. $2 \mathrm{~A}$ ) and the arctic fish a faint band of $\approx 0.85 \mathrm{~kb}$ (Fig. $3 \mathrm{~A}$ ). Eel ANP and eel VNP mRNA have been reported to be $0.8 \mathrm{~kb}$ and $1 \mathrm{~kb}$ respectively (Takei et al. 1994b, 1997), which is significantly smaller in size than the mRNA detected with the full-length sCP cDNA probe in the present study. The intensity of the signals was quantified with densitometry and normalised to the r18S RNA in the same samples (Figs 2B and 3B). Because the extent of sequence dissimilarity between species is not known, a meaningful interspecies comparison of the mRNA levels is not feasible. However, since it is likely that a homologous single copy gene encodes the peptide in different species, it is possible to compare the distribution of $\mathrm{sCP}$ mRNA in the two chambers of the heart of a given species. The comparison showed that the levels of sCP mRNA in the atrium and ventricle do not always go hand-in-hand with the corresponding immunoreactive peptide levels. In vendace, for example, with high atrium to ventricle ir-sCP ratio, the corresponding mRNA ratio was the lowest (Fig. 2B).

\section{Distribution of ir-sCP in the plasma of different species}

Plasma was extracted prior to assay with SepPak $\mathrm{C}_{18}$ cartridges to concentrate the samples and to prevent

Table 1 Distribution of ir-sCP in the heart and plasma of different teleosts. Results are given as means \pm S.E.M.

\begin{tabular}{|c|c|c|c|c|}
\hline & $n$ & Atrium $(\mathrm{nmol} / \mathrm{g})$ & Ventricle $(\mathrm{nmol} / \mathrm{g})$ & Plasma (pmol/l) \\
\hline \multicolumn{5}{|l|}{ Species } \\
\hline Salmon & 10 & $54 \cdot 6 \pm 3 \cdot 9$ & $7 \cdot 4 \pm 0 \cdot 9$ & $307 \pm 41$ \\
\hline Landlocked salmon & 5 & $39 \cdot 4 \pm 3 \cdot 7$ & $11 \cdot 9 \pm 0 \cdot 8$ & $319 \pm 17$ \\
\hline Brown trout & 5 & $58 \cdot 9 \pm 14 \cdot 6$ & $2 \cdot 7 \pm 0 \cdot 3$ & $527 \pm 124$ \\
\hline Sea trout & 1 & $44 \cdot 7$ & $<4$ & \\
\hline Rainbow trout & 5 & $40 \cdot 2 \pm 5 \cdot 5$ & $18 \cdot 4 \pm 2 \cdot 2$ & $374 \pm 64$ \\
\hline Lake trout & 5 & $13 \cdot 5 \pm 1 \cdot 4$ & $2 \cdot 9 \pm 0 \cdot 4$ & $204 \pm 14$ \\
\hline Arctic char & 1 & $24 \cdot 2$ & $<4$ & \\
\hline Grayling & 5 & $8 \cdot 0 \pm 0 \cdot 7$ & $2 \cdot 3 \pm 0 \cdot 3$ & $340 \pm 79$ \\
\hline Vendace & 7 & $121 \cdot 9 \pm 12 \cdot 0$ & $4 \cdot 1 \pm 0 \cdot 4$ & $16090 \pm 5180$ \\
\hline Migrating whitefish & 5 & $54 \cdot 4 \pm 6 \cdot 6$ & $6 \cdot 6 \pm 0 \cdot 7$ & $6000 \pm 497$ \\
\hline C. pallasi & 5 & $53 \cdot 8 \pm 3 \cdot 5$ & $7 \cdot 3 \pm 0 \cdot 9$ & $2986 \pm 198$ \\
\hline
\end{tabular}


ค.
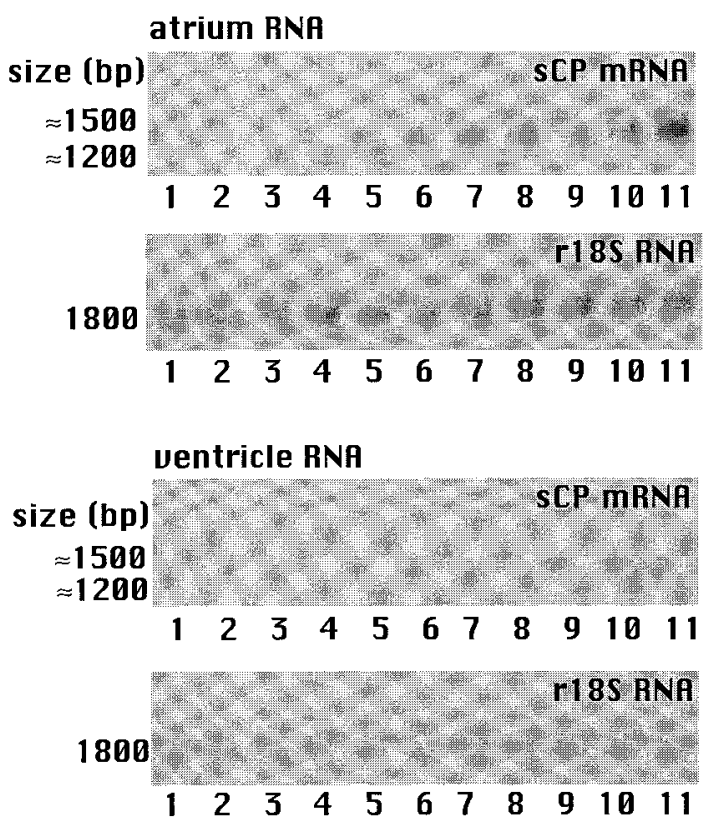

B.

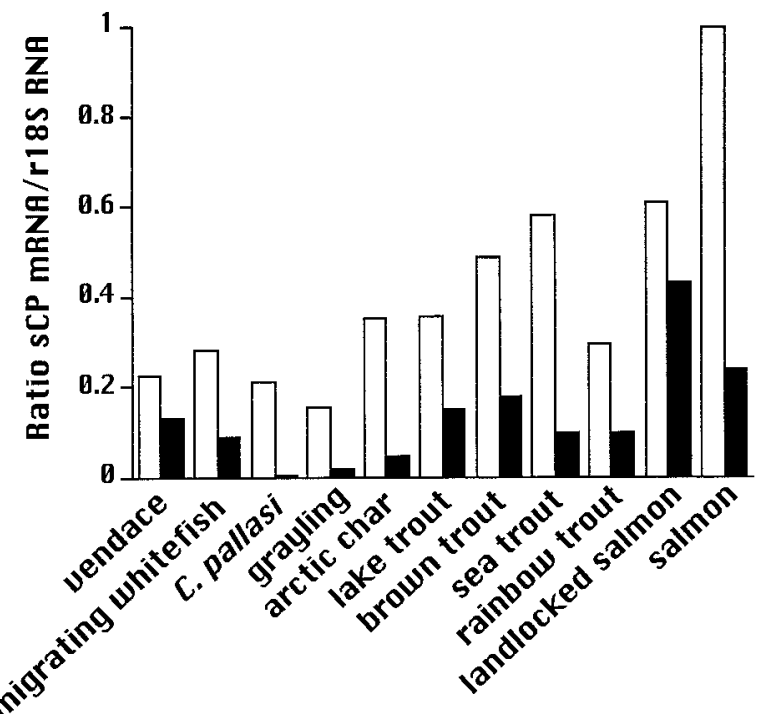

Figure 2 (A) Distribution of sCP mRNA in the atrium and ventricle of different fish species as studied by RNA blot analysis. Species: 1 , vendace; 2 , migrating whitefish; 3 , C. pallasi; 4, grayling; 5 , arctic char; 6 , lake trout; 7 , brown trout; 8 , sea trout; 9 , rainbow trout; 10, landlocked salmon; 11, salmon. (B) Distribution of sCP mRNA calculated by normalising the individual SCP signals to the corresponding $\mathrm{r} 18 \mathrm{~S}$ signals. The open bars denote atrial and the closed ventricular signals.

non-specific interference in the RIA by components of plasma. Salmon caudal vein plasma extracts were found to contain $307 \pm 41 \mathrm{pmol} / 1 \mathrm{ir}-\mathrm{sCP}(n=10)$, a level which is f.

\section{heart RNA}
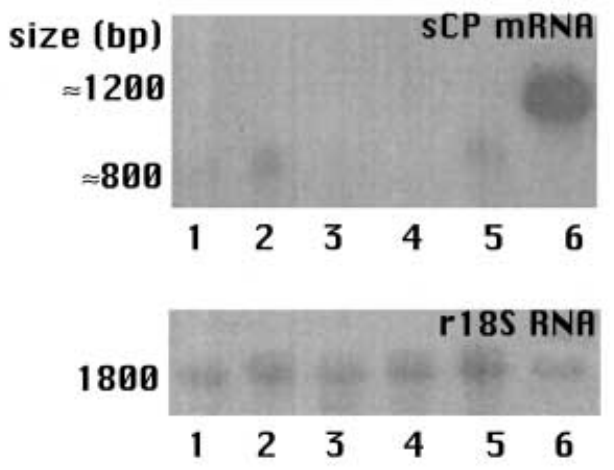

B.

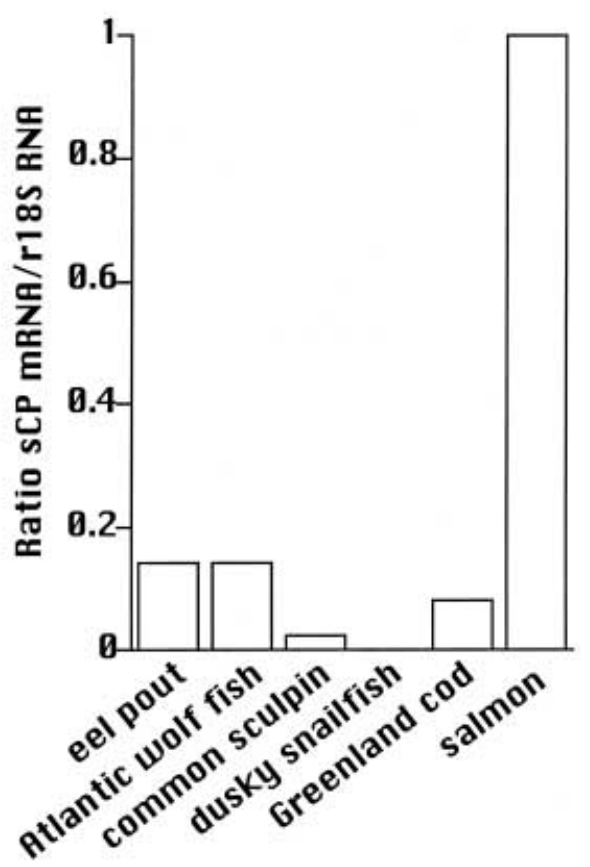

Figure 3 (A) Distribution of $\mathrm{sCP}$ mRNA in arctic fish hearts as studied by RNA blot analysis. Species: 1, eel pout; 2, Atlantic wolf fish; 3, common sculpin; 5, Greenland cod, but not in 4, dusky snailfish. Salmon atrium RNA (6) was used as a size reference. (B) Distribution of sCP mRNA calculated by normalising the individual SCP signals to the corresponding r18S signals.

several times higher than that reported previously for ANP and BNP in mammalian plasma (Table 2). In the ventral aorta the level was significantly higher, $1815 \pm 436 \mathrm{pmol} / 1$ $(n=6, P<0 \cdot 01)$, indicating a fast elimination of plasma $\mathrm{sCP}$, analogous to that found previously for ANP in the mammalian circulation. The highest plasma levels of ir-sCP were detected in vendace, with the remarkable concentration of $16090 \pm 5180 \mathrm{pmol} / \mathrm{l}$ ir-sCP (Table 1), which is clearly the highest of any natriuretic peptide in any species studied thus far. Very high levels of plasma 
Table 2 Plasma concentrations of ir-sCP and ir-ANP, ir-BNP and ir-VNP in different species

\begin{tabular}{|c|c|c|c|}
\hline & Species, source & $\begin{array}{l}\text { Concentration } \\
(\mathrm{pmol} / \mathrm{l})\end{array}$ & Reference \\
\hline \multicolumn{4}{|l|}{ Peptide } \\
\hline sCP & Salmon, caudal vein & $307 \pm 41$ & This study \\
\hline \multirow[t]{5}{*}{ ANP } & Eel, ventral aorta & 248 & Takei et al. 1994a \\
\hline & Pig, decapitated & $21-51$ & Aburaya et al. 1989 \\
\hline & Rat, abdominal aorta & 45 & Leskinen et al. 1995 \\
\hline & Man, atrial plasma & $27 \cdot 9$ & Arjamaa et al. 1996 \\
\hline & Man, venous plasma & 9 & Arjamaa et al. 1996 \\
\hline \multirow[t]{3}{*}{ BNP } & Pig, decapitated & $1-3$ & Aburaya et al. 1989 \\
\hline & Rat, abdominal aorta & 35 & Leskinen et al. 1995 \\
\hline & Man, venous plasma & $0 \cdot 9$ & Mukoyama et al. 1991 \\
\hline VNP & Eel, ventral aorta & 882 & Takei et al. 1994a \\
\hline
\end{tabular}

ir-sCP were also measured from the other coregonids. Relatively high concentrations of ir-sCP, compared with natriuretic peptide plasma concentrations in mammals, were detected in the plasma of all the remaining fish species studied, varying from $204 \pm 14 \mathrm{pmol} / 1$ in lake trout to $527 \pm 124 \mathrm{pmol} / \mathrm{l}$ in brown trout.

\section{Molecular form of stored and secreted ir-sCP}

To obtain a preliminary characterisation of the nature of ir-sCP present in the heart and plasma of different fish species, the extracts were separated with gel filtration HPLC and the fractions were monitored by sCP RIA. In salmon atrial and ventricular extracts, the immunoreactivity consisted almost exclusively of high molecular weight material (>10 kDa) (Fig. 4A), which probably corresponds to pro-sCP. In contrast, ir-sCP in the plasma extracts was due to approximately $3 \mathrm{kDa}$ material, which coelutes with the 29 amino acid synthetic sCP standard. Very little high molecular weight material was detected in salmon plasma (Fig. 4B). An isolated perfused salmon ventricle preparation was used as a model system in which it was possible to exclude the possibility that plasma-derived proteases or the extraction procedure of plasma samples cause artefactual conversion from high to low molecular weight immunoreactive material. Immunoreactive sCP in the perfusate, whether fractionated directly or after SepPak extraction, was of the low molecular weight variant and eluted identically with that extracted from plasma. A $10 \mathrm{mmHg}(1.33 \mathrm{kPa})$ increase of load caused an over fivefold increase of ir-sCP release into the perfusate, from $264 \pm 88 \mathrm{pmol} / \mathrm{l} / \mathrm{g}$ ventricle tissue to $1380 \pm 322 \mathrm{pmol} / 1$ per $\mathrm{g}$ ventricle tissues, but it did not alter the gel filtration pattern of immunoreactive sCP in the perfusate (Fig. 4B). Moreover, ir-sCP in extracts of the perfused ventricle had the same high molecular weight as that extracted from fresh salmon ventricle (data not shown).

Extension of the gel filtration HPLC analysis to the other fish species revealed a very similar elution pattern for the atrial ir-sCP in all the fish belonging to the genus Salmo (salmon, landlocked salmon, brown trout and sea trout) and Salvelinus (lake trout and arctic char), with the main immunoreactive peak eluting in fraction 14 (Figs 4A and 5). Another group, according to the elution pattern, is formed by the coregonids and rainbow trout, with the ir-sCP peak being broader, comprising fractions 14 and 15. This suggests that in these species the high molecular weight ir-sCP is of a slightly smaller size than in salmon, or that there are additional immunoreactive components. On the other hand, the sharp main peak of immunoreactive sCP in the ventricle tended to elute slightly later than the atrial peak in the salmon, landlocked salmon, brown trout and sea trout, suggesting that the molecular weight of pro-sCP in the ventricle might be lower than that in the atrium (Figs 4A and 5). The ventricle of arctic char contained almost equal amounts of the high and low molecular weight immunoreactive material, in contrast to the other species studied.

Immunoreactive sCP in SepPak extracts of plasma were composed of varying amounts of the high and low molecular weight material in different fish species (Figs 4B and 6). In landlocked salmon and rainbow trout all of the immunoreactive material eluted identically with the synthetic sCP-29 used for calibration of the column. A small amount of high molecular weight immunoreactive material was additionally detectable in salmon plasma. In lake trout, both high and low molecular weight material was present, at the ratio of approximately $37 \%$ to $63 \%$. On the other hand, $87 \%$ of the immunoreactivity was due to high molecular weight material in brown trout. Finally, in coregonids the immunoreactivity consisted almost exclusively of the high molecular weight, pro-sCP-sized material.

\section{Discussion}

In the present study, we found by Northern blot analysis, that a gene homologous to that of the novel sCP hormone 
A

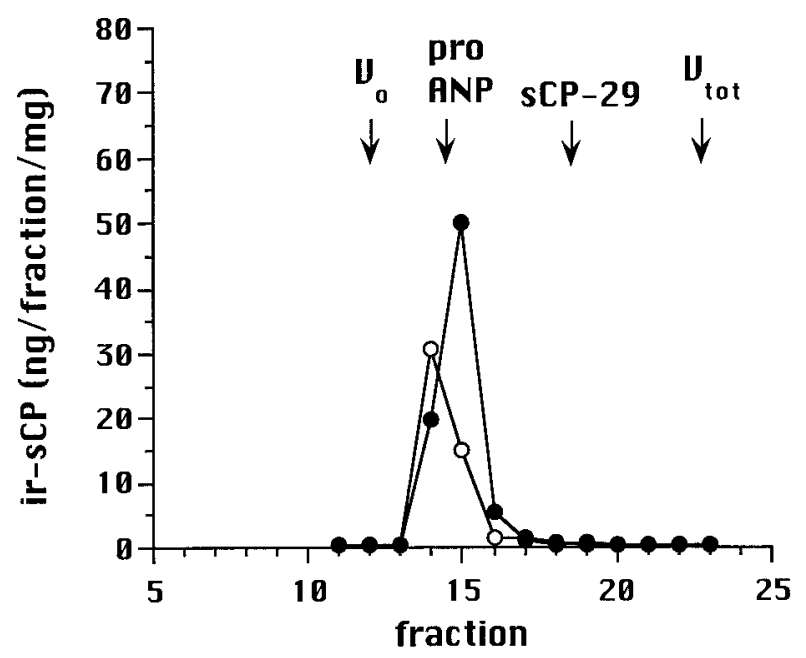

B

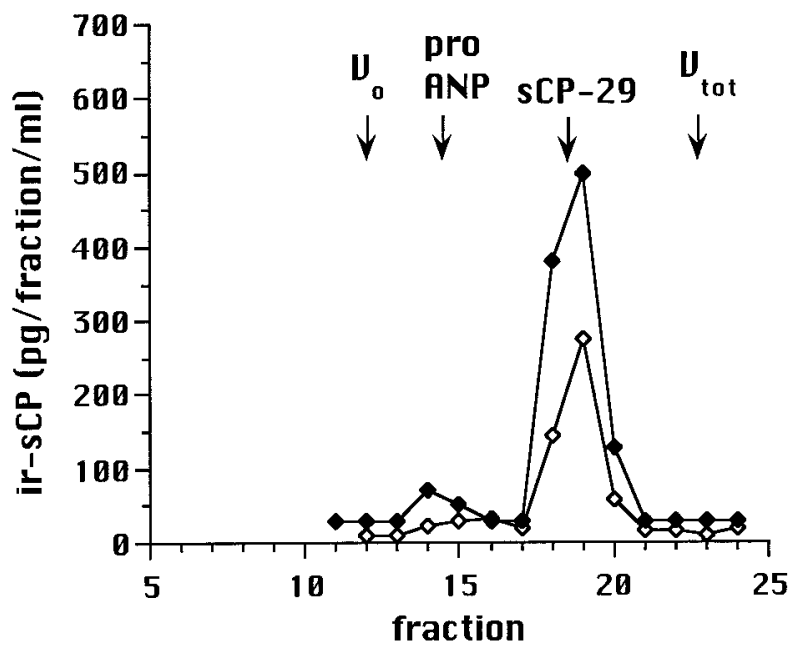

Figure 4 (A) Molecular form of sCP as assessed by gel filtration HPLC in homogenates of salmon atrium $(\bigcirc)$ and ventricle $(\bullet)$. (B) Molecular form of sCP in extracts of salmon ventricle perfusate $(\diamond)$ and plasma $(\bullet)$. The elution positions of BSA $\left(\mathrm{V}_{0}\right)$, human proANP, sCP-29 and ${ }^{125} \mathrm{I}\left(\mathrm{V}_{\text {tot }}\right)$, used for calibration of the column, are shown by arrows.

is expressed in the heart, but not in other tissues, of a large variety of teleost species. Moreover, by setting up a specific RIA for the salmon peptide we found that sCP-like immunoreactivity can be found in the heart and plasma of a majority of the species, suggesting that an sCP-like hormone has a general endocrine function in fish physiology. Using gel filtration HPLC to characterise the molecular size of sCP immunoreactivity in the heart and plasma of different species, we found that the tissue storage form, both in the atrium and ventricle, invariably corresponds to a high molecular weight, pro-sCP-sized peptide. Depending on the species, the storage form is then partially or totally processed to low molecular weight, sCP-sized peptide, apparently in conjunction with the exocytosis of the peptide. Finally, studies with isolated perfused salmon ventricle demonstrated that, at least in this species, the processing does not depend on proteases present in plasma, nor is it modified with stimulation of the hormone release by mechanical load.

At first glance, sCP and peptides homologous to it seem to be specific for teleosts, since no mRNA or ir-sCP was detected in other animals, ranging from cyclostomata to mammals. However, the relatively stringent conditions used in Northern blot analysis necessitate a fairly close homology for the hybridising mRNA species. In addition, in RIA a critically placed difference of even a single amino acid in the peptide sequence can totally abolish immunoreactivity.

Among the teleosts studied, coregonids differed markedly from the other species, not only by the high levels of immunoreactive sCP present in their heart and plasma, but also by the plasma molecular form of the immunoreactivity. While the sole or major molecular form of circulating ir-sCP corresponds in size to the 29 amino acid sCP in the other species, the main form of both stored and circulating peptide in coregonids has the size of pro-sCP. This indicates that the processing and possibly secretion mechanisms of pro-sCP-like peptides differ from those in other fish species. The reason for and physiological significance of this anomaly is not yet known.

In previous studies, the expression of natriuretic peptide genes, although often very predominant in the heart, has been found not to be strictly cardiac-specific. Mammalian ANP and BNP genes are expressed, in addition to the heart, in several extracardiac tissues, such as the central nervous system and gonads (Dagnino et al. 1991, Ruskoaho 1992). Likewise, eel ANP and eel VNP have been found to be cardiac hormones, but significant extracardiac synthesis appears to take place as well, e.g. in the brain (Takei et al. 1994a). In mammals, the production of CNP takes place almost exclusively outside the heart (Minamino et al. 1993). In elasmobranch shark, the tissue distribution of CNP was also found to be wide, although the heart contains the highest concentration (Suzuki et al. 1994). In the frog, CNP II is widely distributed in peripheral tissue (Kojima et al. 1994). In contrast to these results, we found, in the present study, the distribution of sCP immunoreactivity to be remarkably heart-specific, not only in the salmon, but in all the other teleost species in which the tissue distribution was studied. Large amounts of ir-sCP were found in the cardiac atrium and ventricle, whereas the levels were below the detection limit in other tissues, such as the brain and gonads. In recent studies with salmon, we have not found any evidence of sCP mRNA outside the heart as studied by quantitative RT-PCR (Majalahti-Palviainen et al. 2000). 

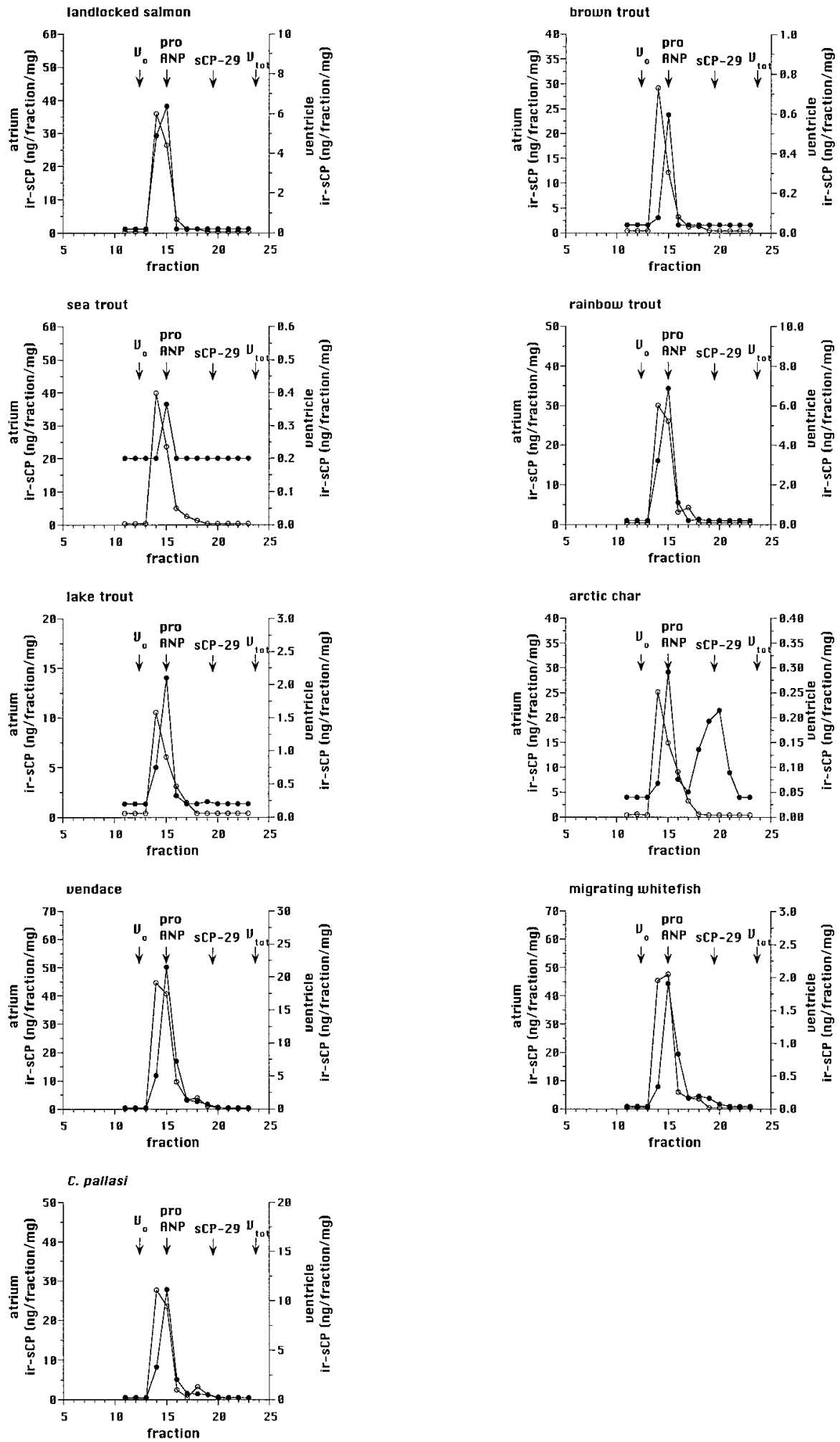

Figure 5 Molecular form of sCP in atrium $(\bigcirc)$ and ventricle $(\bullet)$ of various teleosts. The elution positions of BSA $\left(\mathrm{V}_{\mathrm{o}}\right)$, human proANP, $\mathrm{sCP}-29$ and ${ }^{125} \mathrm{I}\left(\mathrm{V}_{\text {tot }}\right)$ are shown by arrows. 

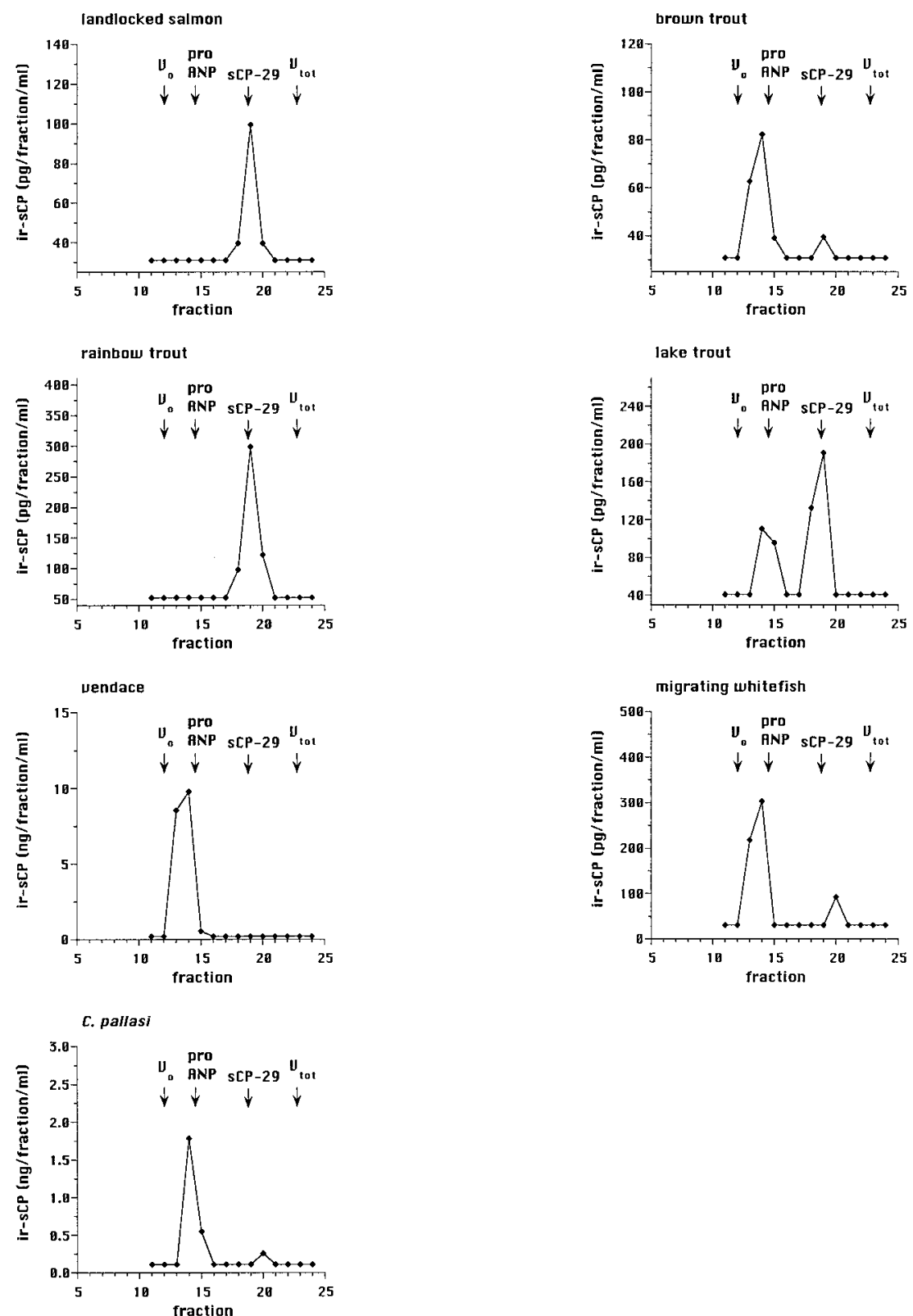

Figure 6 Molecular form of sCP in plasma extract of various teleosts. The elution positions of $\operatorname{BSA}\left(\mathrm{V}_{\mathrm{o}}\right)$, human proANP, sCP-29 and ${ }^{125} \mathrm{I}\left(\mathrm{V}_{\text {tot }}\right)$ are shown by arrows.

Thus sCP and its homologues in other species appear to be the most heart-specific hormone among the natriuretic peptide family found thus far. Our recent finding that the salmon sCP gene promoter can drive the expression of a luciferase reporter in primary cultures of rat atrial myocytes as efficiently as the promoter of rat ANP (MajalahtiPalviainen et al. 2000) suggests that teleost sCP promoter contains the general elements required for cardiac gene expression. This makes teleost sCP an excellent model for studying the mechanisms of cardiac gene expression and regulation.
The concentration of sCP in both atrium and ventricle of salmon is remarkably high, as shown in Table 1. The presence of a high concentration in both chambers of the heart is exceptional among the natriuretic peptides. In eel and mammalian heart, the atria are the major source of ANP (Ueda et al. 1991, Minamino et al. 1993, Takei et al. 1994a). In mammals, BNP is thought of as a ventricular hormone, because it is predominantly released from the ventricles (Ogawa et al. 1991). However, the ventricle to atrium ratio of sCP in salmon is still several times higher than that of BNP in mammals. On the other hand, the 
atrium to ventricle ratio of $\mathrm{sCP}$ in vendace $(1 / 33)$ and brown trout $(1 / 23)$ resembles that of mammalian BNP $(1 / 25)$. In eel, the concentration of the VNP is three times higher in the ventricle than in the atrium, thus indicating the ventricle to be the major source of the peptide (Takei et al. 1994a). Among the natriuretic peptides, only the distribution of CNP in dogfish bears a resemblance to that of sCP in salmon, being three times higher in the atrium than in the ventricle (Suzuki et al. 1994). The CNP of sharks, however, share few structural characteristics with sCP. They are, according to structure, typical representatives of the C-type subgroup of the natriuretic peptide family (Schofield et al. 1991, Suzuki et al. 1991). Thus, with regard to tissue distribution, $\mathrm{sCP}$ does bear some resemblance to mammalian BNPs and elasmobranch CNPs, but it differs clearly from them in structure.

We found by gel filtration HPLC analysis that the storage form of ir-sCP differs markedly from the circulating form. Although gel filtration cannot resolve the exact length of the peptide chain, our results suggest that the major or sole storage form corresponds to the full-length or near full-length pro-sCP of 126 amino acids, whereas the predominant form in the plasma of most of the teleost species studied behaves identically with the 29 amino acid biologically active sCP. The fact that we found a similar difference in the stored and secreted forms when using an isolated perfused salmon ventricle preparation rules out the possibility that plasma proteases are responsible for the conversion from high to low molecular weight immunoreactive $\mathrm{sCP}$. This resembles the way mammalian proANP is processed in atrial myocytes (Vuolteenaho et al. 1985) and which appears to be the case with eel proANP and proVNP as well (Takei et al. 1994a). Although the original finding in mammals was made more than a decade ago, the mechanisms of processing are still largely unknown.

The molecular and cellular mechanisms of processing of pro-sCP to the 29 amino acid residue sCP appear remarkably similar to those of mammalian proANP. The maturation of pro-sCP takes place by proteolysis of an Arg-Ser bond (Tervonen et al. 1998), as is the case with proANP. Moreover, this event occurs during or very close to exocytosis of the secretory granules, since the peptide stored in the heart consists almost solely of pro-sCP-sized material, while the secreted peptide is due to sCP-sized material. Finally, the furin motif Arg-X-X-Arg (Sawada et al. 1997) is not present in pro-sCP (Tervonen et al. 1998), precluding BNP-type processing. On the other hand, it is interesting to note that the gene, cDNA and amino acid sequence of sCP (Tervonen et al. 1998, Majalahti-Palviainen et al. 2000) show a mixture of features typical of all three previously known mammalian natriuretic peptide subgroups, ANP, BNP and CNP. The fact that we found a variation in the relative amounts of pro-sCP- and sCP-sized peptides in the plasma in some of the teleosts, the coregonids in particular, indicates that the processing mechanisms of pro-sCP or their efficiency may differ between species. It is, however, not likely that the overall sequences of sCP mRNA or the peptide diverge very much between the different teleosts, considering the ease with which we could detect them using high stringency RNA blots and a very specific sCP RIA.

Natriuretic peptides have been studied extensively, mostly in mammals, because of their importance in the regulation of volume balance and cardiovascular function. The cellular mechanisms of the processing and release from the heart are fundamental in understanding the structure-function relationships important for the function of the natriuretic peptides. The characteristics found to be common in different vertebrate species suggest the importance of these factors in general regulation of the natriuretic peptide system. The similarities in the storage, processing and secretion of $\mathrm{sCP}$ in fish to that of mammalian ANP provide new models for studies on the physiology of the natriuretic peptide system. Considering the extreme tissue specificity of $\mathrm{sCP}$, it might help in defining the general molecular machinery required for heart-specific gene expression.

\section{Acknowledgements}

We thank Mr Matti Karjalainen and other personnel of the Game and Fisheries Institute in Taivalkoski for providing the fish for the study. We would like to thank Dr Art DeVries at the University of Illinois at UrbanaChampaign, USA for the arctic fish hearts, Dr Mikko Nikinmaa at the University of Turku, Finland for the lamprey hearts, and Dr Sighvatur Arnason at the University of Reykjavik, Iceland for the fin whale heart tissue samples. We wish to thank Tuula Taskinen, Ulla Pohjoisaho and Alpo Vanhala for expert technical assistance. This study was supported by grants from the Academy of Finland and Sigrid Jusélius Foundation.

\section{References}

Aburaya M, Minamino N, Kangawa K, Tanaka K \& Matsuo H 1989 Distribution and molecular forms of brain natriuretic peptide in porcine heart and blood. Biochemical and Biophysical Research Communications $165872-879$.

Arjamaa O, Karlqvist K, Vainionpää V, Leppäluoto J \& Vuolteenaho O 1996 Atrial plasma ANP and $\mathrm{NH}_{2}$-terminal proANP during right atrial pressure increase in humans. Acta Physiologica Scandinavica 157 481-485.

Chomczynski P \& Sacchi N 1987 Single-step method of RNA isolation by acid guanidium thiocyanate-phenol-chloroform extraction. Analytical Biochemistry 162 156-159.

Dagnino L, Drouin J \& Nemer M 1991 Differential expression of natriuretic peptide genes in cardiac and extracardiac tissues. Molecular Endocrinology 5 1292-1300.

Hunter WM \& Greenwood FC 1962 Preparation of iodine-131 labeled human growth hormone of high specific activity. Nature 194 495-496. 
Kojima M, Ohyama Y, Miyamoto K, Minamino N, Kangawa K \& Matsuo H 1994 Cloning and characterization of a novel natriuretic peptide in frog (Rana catesbeiana). Journal of Biological Chemistry 269 $13136-13140$

Leskinen H, Vuolteenaho O, Leppäluoto J \& Ruskoaho H 1995 Role of nitric oxide on cardiac hormone secretion: effect of NG-nitro-L-arginine methyl ester on atrial natriuretic peptide and brain natriuretic peptide secretion. Endocrinology 136 1241-1249.

Majalahti-Palviainen T, Hirvinen M, Tervonen V, Ilves M, Ruskoaho $\mathrm{H} \&$ Vuolteenaho O 2000 Gene structure of a new cardiac peptide hormone: a model for heart-specific gene expression. Endocrinology 141 731-740.

Mukoyama M, Nakao K, Hosada K, Suga S, Saito Y, Ogawa Y, Shirakami G, Jougasaki M, Obata K, Yasue H, Kambayashi Y, Inouye K \& Imura H 1991 Brain natriuretic peptide as a novel cardiac hormone in humans. Journal of Clinical Investigation $\mathbf{8 7}$ 1402-1412.

Minamino N, Aburaya M, Kojima M, Miyamoto K, Kangawa K \& Matsuo H 1993 Distribution of C-type natriuretic peptide and its messenger RNA in rat central nervous system and peripheral tissue. Biochemical and Biophysical Research Communications 197 326-335.

Ogawa Y, Nakao K, Mukoyama M, Hosoda K, Shirakami G, Itoh H, Arai H, Saito Y, Suga S, Jougasaki M \& Imura H 1991 Natriuretic peptides as cardiac hormones in normotensive and spontaneously hypertensive rats. The ventricle is the major site of synthesis and secretion of brain natriuretic peptide. Circulation Research 69 491-500.

Powers DA 1989 Fish as model systems. Science 246 352-358.

Ruskoaho H 1992 Atrial natriuretic peptide: synthesis, release, and metabolism. Pharmacological Reviews 44 479-601.

Sawada Y, Syda M, Yokohama H, Kanada T, Sakamaki T, Tanaka S, Nagai R, Abe S \& Takeuchi T 1997 Stretch-induced hypertrophic growth of cardiocytes and processing of brain-type natriuretic peptide are controlled by proprotein-processing endoprotease furin. Journal of Biological Chemistry 272 20545-20554.

Schofield JP, Jones DSC \& Forrest N Jr 1991 Identification of C-type natriuretic peptide in heart of spiny dogfish shark (Squalus acanthias). American Journal of Physiology 261 F734-F739.

Suzuki R, Takahashi A, Hazon N \& Takei Y 1991 Isolation of high-molecular-weight C-type natriuretic peptide from the heart of a cartilaginous fish (European dogfish, Scyliorhinus canicula). FEBS Letters 282 321-325.
Suzuki R, Togashi K, Ando K \& Takei Y 1994 Distribution and molecular forms of C-type natriuretic peptide in plasma and tissue of a dogfish, Triakis scyllia. General and Comparative Endocrinology 96 378-384.

Takei Y, Takahashi A, Watanabe TX, Nakajima K \& Ando K 1994a Eel ventricular natriuretic peptide: isolation of a low molecular size form and characterization of plasma form by homologous RIA. Journal of Endocrinology 141 81-89.

Takei Y, Ueki M \& Nishizawa T $1994 b$ Eel ventricular natriuretic peptide: cDNA cloning and mRNA expression. Journal of Molecular Endocrinology 13 339-345.

Takei Y, Ueki M, Takahashi A \& Nishizawa T 1997 Cloning, sequence analysis, tissue-specific expression and prohormone isolation of eel atrial natriuretic peptide. Zoological Science $\mathbf{1 4}$ 993-999.

Tervonen V, Arjamaa O, Kokkonen K, Ruskoaho H \& Vuolteenaho O 1998 A novel cardiac peptide hormone related to A-, B- and C-type natriuretic peptides. Endocrinology 139 4021-4025.

Torczynski RM, Bollon AP \& Fuke M 1983 The complete nucleotide sequence of the rat $18 \mathrm{~S}$ ribosomal RNA gene and comparison with the respective yeast and frog genes. Nucleic Acids Research $\mathbf{1 1}$ 4879-4890.

Ueda S, Minamino N, Aburaya M, Kangawa K, Matsukura S \& Matsuo H 1991 Distribution and characterization of immunoreactive porcine C-type natriuretic peptide. Biochemical and Biophysical Research Communications 175 759-767.

Vuolteenaho O, Leppäluoto J, Vakkuri O, Karppinen J, Höyhtyä M \& Ling N 1981 Development and validation of a RIA for beta-endorphin-related peptides. Acta Physiologica Scandinavica 112 313-321.

Vuolteenaho O, Arjamaa O \& Ling N 1985 Atrial natriuretic polypeptides (ANP): rat atria store high molecular weight precursor but secrete processed peptides of 25-35 amino acids. Biochemical and Biophysical Research Communications 129 82-88.

Received 22 October 1999

Revised manuscript received 22 February 2000 Accepted 6 April 2000 